\title{
Emergencies in obese patients: a narrative review
}

\author{
Ida Di Giacinto ${ }^{1}$, Martina Guarnera ${ }^{2}$, Clelia Esposito ${ }^{3}$, Stefano Falcetta ${ }^{4}$, Gerardo Cortese ${ }^{5}$, Giuseppe Pascarella ${ }^{6^{*}}$ (D), \\ Massimiliano Sorbello ${ }^{7}$ and Rita Cataldo ${ }^{6}$
}

\begin{abstract}
Obesity is associated to an increased risk of morbidity and mortality due to respiratory, cardiovascular, metabolic, and neoplastic diseases. The aim of this narrative review is to assess the physio-pathological characteristics of obese patients and how they influence the clinical approach during different emergency settings, including cardiopulmonary resuscitation. A literature search for published manuscripts regarding emergency and obesity across MEDLINE, EMBASE, and Cochrane Central was performed including records till January 1, 2021. Increasing incidence of obesity causes growth in emergency maneuvers dealing with airway management, vascular accesses, and drug treatment due to both pharmacokinetic and pharmacodynamic alterations. Furthermore, instrumental diagnostics and in/out-hospital transport may represent further pitfalls. Therefore, people with severe obesity may be seriously disadvantaged in emergency health care settings, and this condition is enhanced during the COVID-19 pandemic, when obesity was stated as one of the most frequent comorbidity. Emergency in critical obese patients turns out to be an intellectual, procedural, and technical challenge. Organization and anticipation based on the understanding of the physiopathology related to obesity are very important for the physician to be mentally and physically ready to face the associated issues.
\end{abstract}

Keywords: Resuscitation, Obesity, Emergency, Cardiac arrest, Trauma

\section{Introduction}

Obese people are characterized by an increased risk of morbidity and mortality and an association between obesity and an increased risk of sudden cardiac death has also been recognized [1-3].

Even a subgroup of obese people known as "metabolically healthy," which do not suffer from comorbidities associated with obesity, has been found to have an increased risk of cardiovascular diseases, stroke, and heart failure [4].

Despite all these possible disorders, from the literature emerges the phenomenon of the obesity paradox [5], that is a better outcome of out-of-hospital post-cardiacarrest obese patients $[6,7]$ as well as better survival in

\footnotetext{
* Correspondence: g.pascarella@unicampus.it

${ }^{6}$ Department of Anesthesia and Intensive Care, Università Campus Bio-Medico, Via Alvaro del Portillo, 200 Rome, Italy

Full list of author information is available at the end of the article
}

case of myocardial infarction, unstable angina, atrial fibrillation, and heart failure compared with normal-weight or underweight patients [8-10]. Several hypotheses have been put forward to explain the phenomenon: first of all, the greater metabolic reserve of individuals with obesity. Secondly, due to the presence of numerous comorbidities, obese patients are more likely to follow appropriate drug therapy [11]. In addition, obese patients often suffer from obstructive sleep apnea (OSA), which exposes them to intermittent periods of hypoxemia predisposing them to systemic protective preconditioning [7]. Obesity is also characterized by an attenuated response of the renin-angiotensin-aldosterone system as well as reduced production of atrial BNP, resulting in the delayed progression towards a symptomatic state of congestive heart failure [12].

The increasing incidence of obesity worldwide is causing an increase in emergency procedures and

(c) The Author(s). 2021 Open Access This article is licensed under a Creative Commons Attribution 4.0 International License, which permits use, sharing, adaptation, distribution and reproduction in any medium or format, as long as you give appropriate credit to the original author(s) and the source, provide a link to the Creative Commons licence, and indicate if changes were made. The images or other third party material in this article are included in the article's Creative Commons licence, unless indicated otherwise in a credit line to the material. If material is not included in the article's Creative Commons licence and your intended use is not permitted by statutory regulation or exceeds the permitted use, you will need to obtain permission directly from the copyright holder. To view a copy of this licence, visit http://creativecommons.org/licenses/by/4.0/. 
resuscitation maneuvers to be performed in obese patients. The current guidelines (Advanced Life Support of the European Resuscitation Council, Advanced Cardiovascular Life Support of the American Heart Association) cite the patient with obesity as a "circumstance or special patient" whose resuscitation treatment does not differ from that of the normalweight adult patient, recognizing the challenges related to the treatment of these patients without providing specific recommendations [13-15].

Since there are no defined guidelines for obese patients in an emergency, the aim of this narrative review is to assess the physiopathological characteristics of obese patients and how they influence the clinical approach during different emergency settings, including cardiopulmonary resuscitation.

\section{Search strategy}

A literature search for published manuscript regarding emergency and obesity across MEDLINE (via PubMed), EMBASE, and Cochrane Central was performed combining the terms "obese," "obesity," "airway," "emergency," "trauma," "cardiac arrest," "cardiopulmonary resuscitation," and "CPR." Randomized controlled trials, observational studies, guidelines, letters to the editor, and case reports published till January 1, 2021, were included in the research strategy.

Search results were limited to publications in English; abstracts from conferences and commentaries were excluded. In the case of a guideline written by the same society or author group and underwent multiple publications, only the latest version was included in the results. All manuscripts underwent title and abstract screening for relevance to the aims of this review; potentially eligible articles were retrieved for full-text review. Screening of all reference lists of relevant studies was also performed, in order to identify any missing publications. Searches; title, abstract, and reference screening; and study selection were performed independently by three investigators (M.G., C.E., S.F.); discrepancies were resolved through consensus by a fourth investigator (G.C.).

\section{Practical tasks for the emergency management of obese patients \\ Vascular access}

Ensuring venous access is a priority in an emergency scenario but can be very difficult and may require numerous venipunctures that predispose the patient to thrombosis and catheter-related infections. The easiest veins to cannulate are those of the antecubital fossa of the arm, if possible with the pressure of a sphygmomanometer rather than a tourniquet.
If no peripheral venous access can be found, placement of central venous access must be considered in spite of obesity-related factors such as the presence of abundant adipose tissue at the access site, which can impede the identification of usual anatomical landmarks; frequently, obese patients are unable to tolerate the Trendelenburg position required for the maneuver [16].

The use of ultrasound in finding the venous, peripheral, and central accesses is mandatory to increase the chances of success and reduce the duration of the procedure and the risk of complications [17].

In this regard, in obese patients, the cephalic vein at the mid-arm may be easily visualized using ultrasound. This vein may be sufficiently deep and stable to be punctured under ultrasound guidance to insert long peripheral cannulas or "short midline" catheters which may constitute stable access for at least 24 h [18].

Alternatives to peripheral and central venous accesses include the intraosseous route, but once again, obesity can present anatomic barriers to successful placement. Kehrl et al. demonstrated that a standard 25-mm intraosseous needle may not be long enough for patients with a body mass index (BMI) $>43 \mathrm{~kg} / \mathrm{m}^{2}$, and an extended $45-\mathrm{mm}$ needle should be used if available [19].

\section{Airway management}

A patient with obesity presents an increased complexity in airway management [20] related mainly to difficult oxygenation. Endotracheal intubation may be more challenging because of anatomical alterations: the patient with obesity can be difficult to ventilate and oxygenate, with a "cannot ventilate, cannot oxygenate" scenario occurring in the worst cases. In emergencies, therefore, even more than in elections, it is essential to be prepared for a difficult airway.

Many factors can influence the prediction and management of a difficult airway: [1] the operator's skills and experience, operative timing, and device and drug availability [2]; the patient's condition such as the level of urgency, state of consciousness and cooperation, gastric content, trauma, and positioning [21, 22]. In addition to the standard difficult airway indexes (Mallampati score, inter-incisive distance, head extension, thyromental distance, edentulism, or presence of fixed teeth or dentures), which are easy to assess even in an emergency if the patient is at least minimally alert and collaborative, there are several specific scores: the circumference of the neck $>41 \mathrm{~cm}$ in women and $>43 \mathrm{~cm}$ in men and the waist-to-hip ratio $>0.9$ [23]. A STOP-Bang score $\geq 5$ is highly suggestive of severe OSA and involves a greater risk of ventilation and difficult intubation, while the MACOCHA score is a valid assessment in case of an intensive care therapy scenario $[24,25]$. 
Guarantee oxygenation in obese patients is a primary issue. If an airway management is needed, it is therefore imperative to provide the patient with adequate preoxygenation at positive pressure up to EtO2 > $90 \mathrm{mmHg}$ with a facial mask, continuous positive airway pressure (CPAP) mask, or high-flow nasal cannula (HFNC) throughout the pre-intubation phase in the ramped or reverse Trendelenburg position [22]. The nasal oxygenation during an effort to secure a tube (NODESAT) technique with a nasal cannula or HFNC can be very useful during airway apneic instrumentation [26]. Endotracheal intubation should follow the "first pass success" approach, that is, the first attempt must be made in the best possible conditions to optimize the chances of success: ramped position and video laryngoscopy or standard laryngoscopy with the tube already mounted on the introducer or stylet, depending on the operator skills are advisable.

If endotracheal intubation fails, ventilation with supraglottic devices or return to the facial mask is imperative. In case proceed without delay to cricothyrotomy after having identified the cricothyroid membrane, using ultrasound can improve the chance of success [27]. Modified rapid sequence induction and intubation (mRSII) does not have a mandatory indication in the patient with obesity; rather, the same indications apply as in non-obese patients (full stomach, symptomatic esophageal reflux, pregnancy, diabetes with gastroparesis) with the addition, however, of any previous bariatric surgery.

The mRSII strategy no longer involves the use of succinylcholine; instead, rocuronium is given at a dose of $1-1.3 \mathrm{mg} / \mathrm{kg}$ of lean body weight (LBW), with a propofol bolus in emergency or urgency conditions. Cardiovascular impairment must be prevented by filling fluids, if possible, and/or vasoactive drug administration. Alternatively, the use of ketamine is allowed.

Numerous studies have been conducted on the ventilation of obese patients in the operating room and in intensive care whose findings are also applicable in the context of emergencies [28].

Protective ventilation helps to reduce the inflammatory response caused by damage to the alveolar-capillary barrier. Low tidal volume (Vt $6-8 \mathrm{ml} / \mathrm{kg}$ according to ideal body weight [IBW] or predicted body weight) avoids ventilation-induced lung injury,; moderate positive end-expiratory pressure (PEEP) $\left(<10 \mathrm{cmH}_{2} \mathrm{O}\right)$ prevents atelectotrauma (the cyclic opening and closing of the alveoli during every respiratory act), and a driving pressure (difference between plateau pressure and PEEP) $<16 \mathrm{cmH}_{2} \mathrm{O}$ avoids barotrauma. It is advisable to use recruiting maneuvers only as a rescue in case of desaturation $[29,30]$.

\section{Emergency transport}

Transport of the patient with pathological obesity can be extremely difficult. Depending on the patient's size and the local circumstances, numerous skilled rescuers may be necessary to lift and transfer the patient to the ambulance. If the patient is found inside a confined space, firefighters are necessary to facilitate transport outside. Stretchers or sheets intended for the transport of heavy weights are available on the market. The helicopter transfer of obese patients could be possible according to their body weight, time/distance of transport, fuel required, and crew member. In-hospital transport can also be problematic: staff must be adequately trained in patient transport, and the hospital must be equipped with suitable devices [31-33].

\section{Diagnostic procedures}

Ultrasonography is the standard technique in emergency diagnostics. However, performing an ultrasound examination in a patient with obesity is technically complex due to the hypo-echogenicity of the adipose tissue and the distance between the skin and the target organs. The use of 2-Mhz probes is recommended, as this allows to reach a greater depth at the expense, however, of spatial resolution.

Due to the patient's size, visualization of the entire body region may not be possible with a single standard $\mathrm{X}$-ray. Some images, such as a lateral view of the cervical spine, are also difficult to interpret. Computerized tomography $(\mathrm{CT})$ and magnetic resonance and magnetic resonance imaging (MRI) devices have size and weight restrictions. Consequently, multiple scans may be necessary, with increased timing, radiation exposure, and the risk of motion artifacts [34].

No clear evidence exist about the first-choice diagnostic exam to perform in this setting, although a lot depends on clinicians' expertise and device availability.

\section{Complex emergency scenarios in obese patients Acute respiratory failure}

Obese people are at higher risk to have acute respiratory failure (ARF) in the presence of other conditions like chronic obstructive pulmonary disease (COPD), asthma, infections, cardiac diseases, and surgery. This predisposition could be strongly related to an underestimated condition, which is called obesity hypoventilation syndrome (OHS) [35].

OHS is a chronic disease associated with respiratory and cardiometabolic impairments leading to a decrease in the ability to perform normal daily activities along with a higher risk of hospitalization and death [36]. It is defined as a combination of obesity (BMI $>30 \mathrm{~kg} / \mathrm{m}^{2}$ ), $\mathrm{PacO} 2>45 \mathrm{mmHg}$, daytime hypercapnia, and disordered breathing during sleep [37]. 
Continuous airway pressure (CPAP) is recommended as the first-line treatment to stable ambulatory patients with OHS and coexistent severe obstructive sleep apnea (OSA) [38].

Non-invasive ventilation (NIV) in intensive care unit (ICU) setting is widely used for the management of acute hypercapnic respiratory failure in these patients, whereas oxygen therapy alone or with the use of CPAP may not resolve hypoventilation [37]. NIV reduces the respiratory load, increases the minute volume for a given breathing effort, and provides ventilation during central apneic events.

Although so far there is a lack of evidence to guide NIV in the population with obesity presenting with ARF, some settings have been underlined: positive end-expiratory airway pressure (PEEP) ranging from 8 to $12 \mathrm{mmHg}$ with minimal pressure support $(8-10$ $\mathrm{cmH}_{2} \mathrm{O}$ ) is commonly required. The respiratory rate should be set to 2-3 breaths/min below the resting respiratory rate. Moreover, prolonging inspiratory time $(\mathrm{Ti})$ increases VT, and a more upright position may help in better ventilation. Finally, volume assured mode may be considered when very high inspiratory pressure is required $[39,40]$.

However, since NIV can have failure rates ranging from 5 to $50 \%$, the delayed recognition of NIV failure may cause intubation delay, increasing morbidity and mortality [40].

When tracheal intubation occurs, a strategy of protective lung ventilation, especially in the coexistence of nosocomial pneumonia, combines low tidal volume (6$8 \mathrm{~mL} / \mathrm{kg}$ based on predicted body weight) and high PEEP (10-15 $\left.\mathrm{cmH}_{2} \mathrm{O}\right)$ [35]. However, in this regard, it should be considered the use of esophageal pressure monitoring in order to choose the best PEEP and optimize mechanical ventilation [41]. In obese patients, especially during the weaning phase, high transpulmonary pressure may be generated, due to excessive respiratory drive combined with vigorous inspiratory efforts and active abdominal muscle contractions, leading to a possible lung injury [42].

Respiratory management of obese patients affected by ARF is summarized in a proposed flowchart (Fig. 1).

\section{Trauma}

Obese patients show characteristic pathophysiologic elements in the context of trauma: limb, pelvis, and thorax injuries are prevalent, with a lower incidence of abdominal and cranial traumas [32, 43].

The assessment of motor, sensory, and reflex functions is more challenging in patients with morbid obesity, because of the size and previous impaired perception of pain and reduced joint mobility and muscle strength due to the weight of the adipose tissue. The entire body surface should then be examined, especially the perineal region and lower abdomen [43].

Primary and secondary transport can be very challenging, requiring special human resources, devices, vehicles, and skills that are not always readily available [44].

A recent survey [45] pointed out the necessity to increase the training of health professionals specifically for these special patients in order to manage the most encountered critical issues: difficulties in patient extraction and transport; the absence of adequate aids, such as collars and spinal boards suitable for obese patients; and diagnostic difficulties and limitations of focused assessment with sonography in trauma (FAST) due to the presence of abundant adipose tissue.

The interaction between body mass and outcome has been incompletely explored, and the evidence of literature is contradictory. Obesity has been associated with increased mortality after motor vehicle collisions, despite comparable or reduced injury severity among obese patients [46-50]. Some have suggested that this demonstrates a "cushion" effect in automobile accidents, and the increased mortality is secondary to other systemic factors. There is some evidence that observed associations between obesity and mortality may have more to do with post-injury care than the injury itself. Morbid obesity is associated with a higher risk of post-traumatic morbidity, a higher incidence of hospitalization in intensive care units, long hospital stay, and more frequent complications such as pulmonary embolism, prolonged mechanical ventilation, infections, bedsores, wound dehiscence, acute renal failure, and multi-organ failure [49, 51-53]. Increasing BMI appears to have a protective effect on mortality in certain disease states, known as "the obesity paradox." [54] Several studies have shown either a U-shaped or a J-shaped relationship between BMI and mortality in which overweight and class I obese patients have increased survival compared to normal weight and underweight patients, with mortality trending upwards in class II and III obesity.

In surgical critical care, obese patients represent a particularly challenging population with intra- and postoperative risk factors; as a patient's BMI increases, their risk of developing surgical complications increases as well. In surgery, obesity resulted in a more significantly longer intervention time, higher intraoperative blood loss, and rate of surgical site infections $[43,55]$.

It is important to monitor blood glucose levels, which can be altered in critical patients with metabolic syndrome or insulin-dependent diabetes mellitus. Care should also be taken to control body temperature, which can easily drop to critical levels in a patient with a large body surface area. This will compromise the outcome, as it increases the risk of postoperative residual 


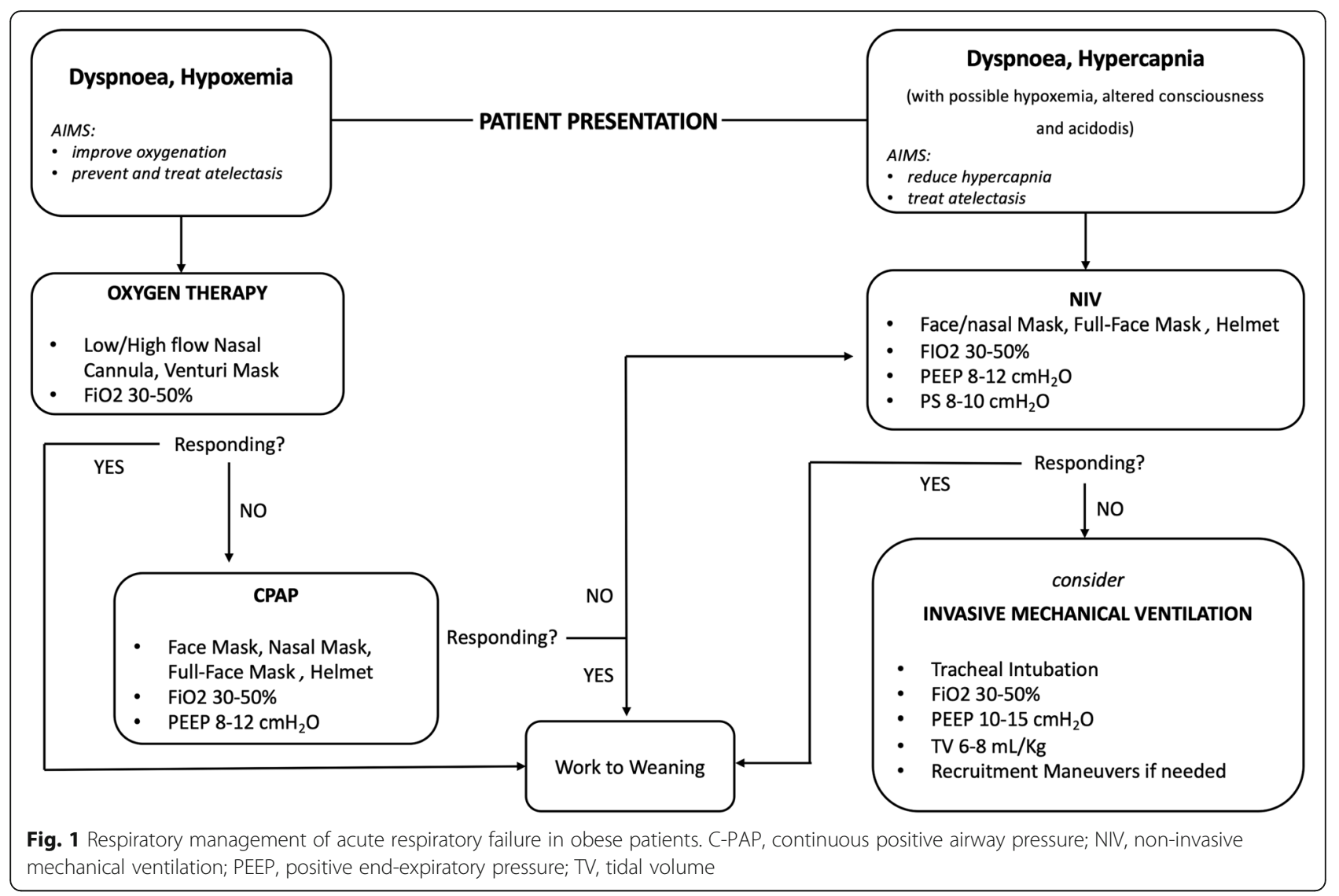

curarization, coagulation impairment, dehiscence of anastomosis or surgical wounds, infections, and decubitus ulcers.

The patients with morbid obesity are often underresuscitated with a slower resolution of base deficit and $\mathrm{pH}$ and a higher mortality from persistent hemorrhagic shock due to relative hypovolemia. It has been demonstrated that an underestimation of volume requirements in the patients may be the cause of decreased cardiac output and tissue oxygenation with poor outcome [56]. The study of Nelson et al. [57] shows that the metabolic derangement in obese patients is not reflected in significantly lower systolic or mean arterial blood pressure, thereby facilitating inadvertent under-resuscitation. They emphasized the need for goal-direct therapy for the resolution of metabolic acidosis and not only for the normalization of hemodynamic parameters.

The metabolic syndrome leads to a hypercoagulable state which needs special attention to the prevention of thromboembolic events. Prevention of deep venous thrombosis can be difficult at best. Mechanical devices often do not fit patients with obesity, and a higher dose of low-molecular-weight heparins may be required to achieve therapeutic antiXA levels. Much of the existing data on venous thromboembolism (VTE) chemoprophylaxis in obese patients are from the experience of the bariatric surgery population. Due to the lack of sufficient data, however, there are no universally accepted VTE chemoprophylaxis recommendations in terms of the pharmacological agents, dosage, frequency, and duration for high-risk obese patients. The greatest consensus in the literature regards the use of enoxaparin at the dosage $0.5 \mathrm{mg} / \mathrm{kg}$ BID, which allows to achieve therapeutic antiXa levels, although it is not associated with a reduction in VTE, increasing the risk of bleeding complications [58].

Finally, obesity is associated with a pro-inflammatory state which affects post-injury inflammatory response with an increased risk of nosocomial infections and organ dysfunction. An active surveillance of biological specimens with early recognition of dangerous microorganisms and a prudent policy of antibiotic administration are both of paramount importance to the preventive rise of multidrug-resistant infections. In motor vehicle accidents, obese people are relatively protected from abdominal and pelvic injuries because of their soft tissues. However, they are more likely to incur a pelvic ring injury, because energy absorbed by the abdomen is transferred to the pelvis. They are also more likely to fracture the peripheral structures such as the distal femur, ankle, or calcaneus and also experience degloving injury. Even with low-energy trauma, they have a tendency to 
experience comminuted fracture with skin and soft tissues injuries, especially the distal end of the long bones. Knee dislocations following low-energy trauma have also been described in obese people, with a high rate of neuromuscular complications, which may require amputation of the leg [59].

The treatment of arm fractures usually requires internal fixation. During orthopedic surgery, given the potential for respiratory complications in the emergence from anesthesia and in the immediate postoperative period, regional anesthesia should always be preferred over general anesthesia whenever possible [60]. However, special considerations should be done for those patients with a prediction of difficult airways. In these cases, as suggested by some authors, the decision should take into account several aspects including patient characteristics, surgical environment, clinician experience, and device availability, over a rescue strategy to manage the airway [61].

\section{Burns}

Pathological obesity is also associated with an increase in mortality in burn patients. The most commonly used methods for determining the burn areas do not take into account BMI. Inaccurate determination of burn size leads to inadequate volume management that can generate serious complications such as hypovolemic shock or deepening of the burn wound. But on the other hand, excessive administration of fluids in obese patients, in association with cardiovascular comorbidities, carries the risk of acute pulmonary edema, abdominal and limb compartment syndrome, and prolongation of mechanical ventilation. The use of the Parkland formula for the administration of liquids, which is one of the main determinants of the survival of a burn patient, should be corrected with IBW $[62,63]$.

\section{Cardiopulmonary resuscitation (CPR)}

The effectiveness of cardiopulmonary resuscitation depends on early defibrillation and quality chest compressions to restore the blood circulation [14, 15].

Cardiopulmonary resuscitation of the adult patient with obesity is not differently described from that in the normal-weight adult: a 30:2 sequence of compressions and ventilations, and compressions performed at a frequency of $100-120 \mathrm{bpm}$, with a depth of $5-6 \mathrm{~cm}$ at the lower half of the sternum, corresponding to the maximum diameter of the left ventricle.

These standard indications for adults obviously do not consider the size of obese patients and the distribution of the adipose tissue. The presence of adipose panniculus on the anterior and posterior chest wall, quantified by computed tomography in an average of $36.53 \mathrm{~mm}$ anteriorly and $50.73 \mathrm{~mm}$ posteriorly, could lead to reduced effectiveness of the compressions [64].

Abdominal fat causes cranial displacement of the diaphragm especially in the supine position, similar to what happens in pregnant women, and in this kind of patients, it is suggested to perform chest compressions to the upper third of the sternum [65]. Lee et al [66] showed, in a retrospective study on CT scan measurements, that the sternum point corresponds to the maximum point of ventricular diameter which in obese people is higher than the usual sternal site of the massage.

Cardiac massage in extremely obese patients is more tiring for operators, with the consequent risk of ineffective chest compressions. The guidelines therefore recommend to switch operators at shorter intervals than the standard 2 min [14]. Obese patients lying in a bed do not necessarily need to be moved onto the floor. Repositioning of obese patients may delay initiation of CPR, but also cause injuries to the patient and rescuers [67].

The use of mechanical chest compression devices might be considered although body dimensions and slope of the anterior chest wall limit usability of most devices. The upper limits include sternum height of 303 or $340 \mathrm{~mm}$ and chest width of 449 or $480 \mathrm{~mm}$ for piston devices, chest circumference of $130 \mathrm{~cm}$, chest width of $380 \mathrm{~mm}$, and body weight of $136 \mathrm{~kg}$ for devices equipped with a load-distributing band $[68,69]$.

Obese patients have higher transthoracic impedance caused by the adipose tissue of the chest wall, but there is no evidence in the literature of a correlation between BMI and the success rate of defibrillation at the first shock. During defibrillation, it is necessary to start with an energy level of $200 \mathrm{~J}$, and the use of modern biphasic defibrillators allows to solve the problem of the increased impedance $[8,13]$. Table 1 summarizes the key issues and optimal strategies regarding CPR in obese patients.

\section{Drug dosage during CPR}

Wang et al. [70] found that patients with a body weight greater than $82.5 \mathrm{~kg}$ may receive an inadequate dose of adrenaline compared with the standards indicated by the guidelines. Gough and Nolan [71] showed, however, that high doses of adrenaline $(>1 \mathrm{mg})$ are associated with an increase in return of spontaneous circulation (ROSC) and survival but also worsening of neurological outcomes after cardiac arrest.

The drugs administered to obese patients during an emergency setting show important pharmacokinetic and pharmacodynamic alterations with respect to normalweight individuals (volume of distribution, protein binding, renal clearance, and hepatic metabolism). As a result, doses need to be adjusted according to IBW, LBW, 
Table 1 Key issues and optimal strategies for CPR in obese patients

\begin{tabular}{|c|c|c|}
\hline & Critical issues & Recommended strategy \\
\hline Vascular access & $\begin{array}{l}\text { The veins on the dorsum of the hand and the deep brachial vein } \\
\text { may be neither visible nor palpable. }\end{array}$ & $\begin{array}{l}\text { The veins of the antecubital fossa of the arm and the external } \\
\text { jugular vein are easier to cannulate. } \\
\text { If available, use ultrasound. } \\
\text { Consider CVC placement or intraosseous route with a } 45-\mathrm{mm} \\
\text { needle. }\end{array}$ \\
\hline $\begin{array}{l}\text { Airway } \\
\text { management }\end{array}$ & $\begin{array}{l}\text { Manual ventilation with bag-mask should be difficult due to ana- } \\
\text { tomical alterations. }\end{array}$ & $\begin{array}{l}\text { Use a two-person technique for bag-mask ventilation. } \\
\text { An experienced clinician should intubate the trachea early. } \\
\text { Consider supraglottic devices if tracheal intubation fails or in } \\
\text { case of difficult facial mask ventilation. }\end{array}$ \\
\hline $\begin{array}{l}\text { Chest } \\
\text { compressions }\end{array}$ & $\begin{array}{l}\text { Thoracic adipose tissue may reduce the effectiveness of the chest } \\
\text { compressions. }\end{array}$ & $\begin{array}{l}\text { Provide chest compressions greater than } 5 \mathrm{~cm} \text { in depth. } \\
\text { Change rescuer performing chest compression more frequently. } \\
\text { If applicable, consider the use of mechanical chest compression. }\end{array}$ \\
\hline $\begin{array}{l}\text { Cardiovascular } \\
\text { drugs }\end{array}$ & $\begin{array}{l}\text { Patients with obesity may receive an inadequate dose of } \\
\text { emergency drugs during CPR. }\end{array}$ & $\begin{array}{l}\text { Adrenaline }-1 \mathrm{mg} \text {. } \\
\text { Amiodarone }-300 \mathrm{mg} \text { first time, } 0.5-0.75 \mathrm{mg} / \mathrm{kg} \text { second time. } \\
\text { Lidocaine }-1-1.5 \mathrm{mg} / \mathrm{kg} \text { according to IBW. } \\
\text { Magnesium sulfate }-2 \mathrm{~g} \text {, repeat after } 10-15 \mathrm{~min} \text {. } \\
\text { Calcium chloride } 10 \%-1 \mathrm{~g} \text {. } \\
\text { Atropine }-0.5 \mathrm{mg} \text {, repeat to a maximum dose of } 3 \mathrm{mg} \text {. } \\
\text { Isoprenaline }-5 \mu \mathrm{g} / \mathrm{min} \text {. } \\
\text { Adrenaline (c.i.) }-2-10 \mu \mathrm{g} / \mathrm{min}\end{array}$ \\
\hline Defibrillation & Higher transthoracic impedance caused by thoracic fat. & Start with an energy level of $200 \mathrm{~J}$ \\
\hline
\end{tabular}

IBW ideal body weight, CVC central venous catheter, c.i continuous infusion

adjusted body weight (ABW), or total body weight (TBW) (Table 2) [44, 72-74].

More studies are needed to optimize cardiopulmonary resuscitation of the obese patient in order to point out specific guidelines for life support, as it happens for other particular patient populations, like the pediatric one [75].

\section{Post-resuscitation care}

Once spontaneous circulation is restored, postresuscitation care begins, consisting of the identification and treatment of the causes that led to the cardiorespiratory arrest along with the assessment and treatment of ischemia-reperfusion injury.

In the meantime, hemodynamic stability [mean arterial pressure $(\mathrm{MAP}) \geq 65 \mathrm{mmHg}$, good oxygenation and normocapnia, glycemic control, and EEG monitoring must be guaranteed [76].

Some studies have investigated therapeutic hypothermia during coma after out-of-hospital cardiac arrest with a shockable rhythm, keeping the body temperature between 32 and $36^{\circ} \mathrm{C}$ for $12-24 \mathrm{~h}$ [77].

However, the use of therapeutic hypothermia is controversial, and a recent evidence suggests its nonsuperiority with respect to normothermia in reducing death incidence at 6 months [78].

Moreover, cooling times are longer in patients with obesity than normal-weight patients [79] and variable depending on the devices used (external or endovascular), and the clinical results are conflicting: some investigators claim a lower mortality and better neurological outcomes [80], while others maintain that a BMI $\geq 30 \mathrm{~kg} / \mathrm{m}^{2}$ is a risk factor for posthypothermic mortality [81].

Various factors must be considered in postresuscitation care, including comorbidities, the cause of the cardiac arrest, the patient's age and sex, the duration of CPR, the concept of the obesity paradox, and the cytokine structure of the obese patients, which predisposes these patients to different ischemia-reperfusion injury. Further randomized clinical trials are needed to obtain more clear-cut results [82].

\section{Special considerations on resuscitation during the COVID- 19 pandemic}

During the COVID-19 pandemic, the Centers for Disease Control and Prevention (CDC) reported in their Morbidity and Mortality Weekly Report of April 17, 2020, that patients hospitalized with COVID-19 had one or more underlying conditions, the most common being hypertension (49.7\%), obesity (48.3\%), chronic lung disease (34.6\%), diabetes mellitus (28.3), and cardiovascular disease (27.8\%) [83-86]. A report on 4103 patients with COVID-19 in New York City found that the most important clinical features leading to hospital admission were age $>65$ years and obesity [87-89]. In Italy, 10.7\% of patients who died of COVID-19 were affected by obesity [90]. Obesity was the most common comorbidity described during the Italian outbreak [91]. Obese patients are also at higher risk of severe complications of COVID-19 [92, 93] by virtue of the obesity-driven increased risk of chronic disease [94]. Moreover, obese patients may develop atelectasis and lung derecruitment, making oxygenation and intubation complicated, hence 
Table 2 Emergency drug dosing in obese patients. Adapted from Cataldo et al. [72]

\begin{tabular}{lll}
\hline Drugs & $\begin{array}{l}\text { Loading } \\
\text { dose }\end{array}$ & Maintenance dose \\
\hline
\end{tabular}

Neuromuscular blockers and antagonists

$\begin{array}{lll}\text { Succynilcholine } & \text { TBW } & - \\ \text { Vecuronium } & \text { IBW } & \text { IBW } \\ \text { Atracurium } & \text { LBW } & \text { LBW } \\ \text { Rocuronium } & \text { LBW } & \text { LBW } \\ \text { Sugammadex } & \text { TBW } & - \\ \text { Neostigmine } & \text { ABW } & -\end{array}$

Sedative hypnotics

Benzodiazepine IBW IBW

Propofol LBW ABW

Thiopental LBW IBW

Phenobarbital TBW IBW

Ketamine TBW IBW

Etomidate $\quad$ TBW -

Dexmedetomidine - LBW

Analgesics

$\begin{array}{llc}\text { Morphine } & \text { LBW } & - \\ \text { Remifentanil } & \text { LBW } & - \\ \text { Fentanil } & \text { LBW } & - \\ \text { Sufentanil } & \text { LBW } & - \\ \text { Alfentanil } & \text { ABW } & - \\ \text { Paracetamol } & \text { LBW } & - \\ \text { Corticosteroids } & & \end{array}$

IBW IBW

Methylprednisolone

Anti-epileptics

$\begin{array}{lll}\text { Phenytoin } & \text { IBW }+[1.33 & \text { IBW } \\ & \times(\mathrm{BBW}- & \\ \text { IBW }] & \\ \text { Valproic acid } & - & \text { IBW } \\ \text { Carbamazepine } & - & \text { IBW } \\ \begin{array}{c}\text { Beta-blockers } \\ \text { Propranolol }\end{array} & \text { IBW } & \text { IBW } \\ \text { Labetalol } & \text { IBW } & \text { IBW } \\ \text { Metoprolol } & \text { IBW } & \text { IBW } \\ \text { Esmolol } & \text { IBW } & \text { IBW } \\ \text { Calcium channel blockers } & \\ \text { Verapamil } & \text { TBW } & \text { IBW } \\ \text { Diltiazem } & \text { TBW } & \text { Titration } \\ \text { Antiarrhythmics } & & \\ \text { Lidocaine } & \text { ABW } & \text { ABW } \\ \text { Procainamide } & \text { IBW } & \text { IBW } \\ \text { Amiodarone } & \text { IBW } & \text { IBW } \\ \text { Digoxin } & \text { IBW } & \text { IBW }\end{array}$

Table 2 Emergency drug dosing in obese patients. Adapted from Cataldo et al. [72] (Continued)

\begin{tabular}{|c|c|c|}
\hline Drugs & $\begin{array}{l}\text { Loading } \\
\text { dose }\end{array}$ & Maintenance dose \\
\hline Adenosine & IBW & IBW \\
\hline \multicolumn{3}{|l|}{ Catecholamines } \\
\hline $\begin{array}{l}\text { Dobutamine } \\
\text { Dopamine } \\
\text { Epinephrine } \\
\text { Norepinephrine } \\
\text { Phenylephrine } \\
\text { Vasopressin } \\
\text { Milrinone }\end{array}$ & & $\begin{array}{l}\text { There are no clinical studies in } \\
\text { obese patients. According to the } \\
\text { literature, ABW or IBW could be } \\
\text { used to avoid overdoses, titrating } \\
\text { the dose as a function of the } \\
\text { clinical target. } \\
\text { ABW in patients } \leq 120 \mathrm{~kg}\end{array}$ \\
\hline
\end{tabular}

IBW for men: height (cm) - 100; IBW for women: height (cm) - 110

$I B W$ ideal body weight, TBW total body weight, $A B W$ adjusted body weight,

$\angle B W$ lean body weight

$A B W=I B W+40 \%$ TBW

$\mathrm{LBW}=$ in men approximately $90 \mathrm{~kg}$, in women approximately $70 \mathrm{~kg}$

putting these patients in the prone position is difficult and risky [95-97].

Recent European Resuscitation Council COVID-19 Guidelines [98] focus to reduce the risk of airborne spread of the virus and to prevent rescuers during CPR, chest compressions, and airway management [99]. But the global pandemic highlighted that appropriate resources for patients with (severe) obesity are often inadequate: for example, access to imaging may be limited by a lack of machines able to accommodate them or by an insufficient number of bariatric beds [100]. Challenges to the healthcare systems include more difficult intubations, more complex lifting and handling demands, and more difficulty to obtain an imaging diagnosis even with pulmonary ultrasound. People with severe obesity may therefore be seriously disadvantaged regarding health care in the COVID-19 era $[101,102]$.

\section{Conclusion}

Even prior to the development of critical illness, obese patients have alterations in respiratory physiology, circulatory physiology, and pharmacokinetics that significantly affect their emergency treatment and resuscitation. Emergency management in critically obese patients is an intellectual, procedural, and technical challenge. Organization and anticipation based on the understanding of the physiopathology related to obesity are very important for the physician to be mentally and physically ready to face the associated issues. Further studies are expected to investigate new techniques and devices capable to improve the efficacy of cardiopulmonary resuscitation and airway management in obese patients, leading to specific guidelines for this particular population.

Authors' contributions

Di Giacinto, Ida: conceptualization, methodology, resources, and writing -original draft. Guarnera, Martina: conceptualization, resources, and 
writing —original draft. Esposito, Clelia: writing — review and editing. Falcetta, Stefano: writing — review and editing. Cortese, Gerardo: writing — review and editing. Pascarella, Giuseppe: literature searching and submission. Sorbello, Massimiliano: conceptualization, resources, and writing-review and editing. Cataldo, Rita: conceptualization, methodology, resources, and writing-original draft and review and editing. The authors read and approved the final manuscript.

\section{Funding}

There is no funding or sponsor.

\section{Declarations}

\section{Competing interests}

MS has received paid consultancy from Teleflex Medical, Verathon Medical, and DEAS Italia; is a patent co-owner (no royalties) of DEAS Italia; and has received lecture grants and travel reimbursements from MSD Italia and MSD USA. ID, SF, and GC have received lecture grants and travel reimbursements from MSD Italia. GC has also received lecture grants and travel reimbursements from Baxter Italia. No external funding or other competing interests declared.

\section{Author details \\ ${ }^{1}$ Unit of Anesthesia and Intensive Care, Mazzoni Hospital, Ascoli Piceno, Italy. ${ }^{2}$ Department of Anesthesia and Intensive Care, Azienda Ospedaliero-Universitaria Sant'Orsola-Malpighi - Alma Mater Studiorum, Bologna, Italy. ${ }^{3}$ Department of Anesthesia and Intensive Care, Ospedali dei Colli, Naples, Italy. ${ }^{4}$ Department of Anesthesia and Intensive Care, Clinica di Anestesia e Rianimazione Ospedali Riuniti Ancona, Ancona, Italy. ${ }^{5}$ Department of Anesthesia and Intensive Care, AOU Città della salute e della scienza Torino, Turin, Italy. ${ }^{6}$ Department of Anesthesia and Intensive Care, Università Campus Bio-Medico, Via Alvaro del Portillo, 200 Rome, Italy. ${ }^{7}$ Department of Anesthesia and Intensive Care, AOU Policlinico San Marco University Hospital, Catania, Italy.}

\section{Received: 9 September 2021 Accepted: 29 October 2021} Published online: 13 November 2021

\section{References}

1. Adabag S, Huxley RR, Lopez FL, Chen LY, Sotoodehnia N, Siscovick D, Deo R, Konety S, Alonso A, Folsom AR (2015) Obesity related risk of sudden cardiac death in the atherosclerosis risk in communities study. Heart 101(3):215221. https://doi.org/10.1136/heartjnl-2014-306238

2. Aune D, Snekvik I, Schlesinger S, Norat T, Riboli E, Vatten $\amalg$ (2018) Body mass index, abdominal fatness, weight gain and the risk of psoriasis: a systematic review and dose-response meta-analysis of prospective studies. Eur J Epidemiol 33(12):1163-1178. https://doi.org/10.1007/s10654-018-0366z

3. Plourde B, Sarrazin JF, Nault I, Poirier P (2014) Sudden cardiac death and obesity. Expert Rev Cardiovasc Ther 12(9):1099-1110. https://doi.org/10.1 586/14779072.2014.952283

4. Caleyachetty R, Thomas GN, Toulis KA, Mohammed N, Gokhale KM, Balachandran K, Nirantharakumar K (2017) Metabolically healthy obese and incident cardiovascular disease events among 3.5 million men and women. J Am Coll Cardiol 70(12):1429-1437. https://doi.org/10.1016/j.jacc.2017.07. 763

5. Chalkias A, Xanthos T (2014) The obesity paradox in cardiac arrest patients Int J Cardiol 171(2):101-102. https://doi.org/10.1016/j.ijcard.2013.11.122

6. Kakavas S, Georgiopoulos G, Oikonomou D, Karayiannis D, Masi S, Karlis G, Xanthos T (2018) The impact of body mass index on post resuscitation survival after cardiac arrest: a meta-analysis. Clin Nutr ESPEN 24:47-53. https://doi.org/10.1016/j.clnesp.2018.01.071

7. Ma Y, Huang L, Zhang L, Yu H, Liu B (2018) Association between body mass index and clinical outcomes of patients after cardiac arrest and resuscitation: a meta-analysis. Am J Emerg Med 36(7):1270-1279. https://doi. org/10.1016/j.ajem.2018.03.079

8. Ogunnaike BO, Whitten CW, Minhajuddin A, Melikman E, Joshi GP, Moon TS, Schneider PM, Bradley SM, American Heart Association's Get With The Guidelines $\left({ }^{\circledR}\right)$-Resuscitation Investigators (2016) Body mass index and outcomes of in-hospital ventricular tachycardia and ventricular fibrillation arrest. Resuscitation 105:156-160. https://doi.org/10.1016/j.resuscitation.2016. 05.028

9. Sakr $Y$, Alhussami I, Nanchal R, Wunderink RG, Pellis T, Wittebole X, MartinLoeches I, François B, Leone M, Vincent $J$, Intensive Care Over Nations Investigators (2015) Being overweight is associated with greater survival in ICU patients: results from the intensive care over nations audit. Crit Care Med 43(12):2623-2632. https://doi.org/10.1097/CCM.0000000000001310

10. Testori C, Sterz F, Losert H, Krizanac D, Haugk M, Uray T, Arrich J, Stratil P, Sodeck G (2011) Cardiac arrest survivors with moderate elevated body mass index may have a better neurological outcome: a cohort study. Resuscitation 82(7):869-873. https://doi.org/10.1016/j.resuscita tion.2011.02.027

11. Lavie CJ, Alpert MA, Arena R, Mehra MR, Milani RV, Ventura HO (2013) Impact of obesity and the obesity paradox on prevalence and prognosis in heart failure. JACC Heart Fail 1(2):93-102. https://doi.org/10.1016/j.jchf.2013. 01.006

12. Krauser DG, Lloyd-Jones DM, Chae CU, Cameron R, Anwaruddin S, Baggish AL, Chen A, Tung R, Januzzi JL Jr (2005) Effect of body mass index on natriuretic peptide levels in patients with acute congestive heart failure: a ProBNP investigation of dyspnea in the emergency department (PRIDE) substudy. Am Heart J 149(4):744-750. https://doi.org/10.1016/j.ahj.2004.07.01 0

13. Cimpoesu D, Corlade-Andrei M, Popa TO et al (2019) Cardiac arrest in special circumstances-recent advances in resuscitation. Am J Ther 26(2): e276-e283. https://doi.org/10.1097/MJT.0000000000000927

14. Truhlář A, Deakin CD, Soar J, Khalifa GEA, Alfonzo A, Bierens JJLM, Brattebø G, Brugger H, Dunning J, Hunyadi-Antičević S, Koster RW, Lockey DJ, Lott C, Paal P, Perkins GD, Sandroni C, Thies KC, Zideman DA, Nolan JP, Barelli A, Böttiger BW, Georgiou M, Handley AJ, Lindner T, Midwinter MJ, Monsieurs KG, Wetsch WA (2015) European resuscitation council guidelines for resuscitation 2015: Section 4. Cardiac arrest in special circumstances. Resuscitation 95:148-201. https://doi.org/10.1016/j.resuscitation.2015.07.017

15. Vanden Hoek TL, Morrison LJ, Shuster M et al (2010) Part 12: Cardiac arrest in special situations: 2010 American Heart Association Guidelines for Cardiopulmonary Resuscitation and Emergency Cardiovascular Care. Circulation 122(18_suppl_3):S829-S861. https://doi.org/10.1161/CIRCULA TIONAHA.110.971069

16. Rupp SM, Apfelbaum JL, Blitt C et al (2012) Practice guidelines for central venous access: a report by the American Society of Anesthesiologists Task Force on Central Venous Access. Anesthesiology 116(3):539-573. https://doi. org/10.1097/ALN.0b013e31823c9569

17. Brandt HG, Jepsen $\mathrm{CH}$, Hendriksen OM, Lindekær A, Skjønnemand M (2016) The use of ultrasound to identify veins for peripheral venous access in morbidly obese patients. Dan Med J 63

18. Scoppettuolo G, Pittiruti M, Pitoni S, Dolcetti L, Emoli A, Mitidieri A, Migliorini I, Annetta MG (2016) Ultrasound-guided "short" midline catheters for difficult venous access in the emergency department: a retrospective analysis. Int J Emerg Med 9(1):3. https://doi.org/10.1186/s12245-016-0100-0

19. Kehrl T, Becker BA, Simmons DE, Broderick EK, Jones RA (2016) Intraosseous access in the obese patient: assessing the need for extended needle length. Am J Emerg Med 34(9):1831-1834. https://doi.org/10.1016/j.ajem.2016.06. 055

20. Godoroja D, Sorbello M, Margarson M (2019) Airway management in obese patients: the need for lean strategies. Trends Anaesth Crit Care 26-27:30-37

21. Higgs A, McGrath BA, Goddard C et al (2018) DAS guidelines on the airway management of critically ill patients. Anaesthesia 73(8):1035-1036. https:// doi.org/10.1111/anae.14352

22. Holmberg TJ, Bowman SM, Warner KJ, Vavilala MS, Bulger EM, Copass MK, Sharar SR (2011) The association between obesity and difficult prehospital tracheal intubation. Anesth Analg 112(5):1132-1138. https://doi.org/1 0.1213/ANE.0b013e31820effcc

23. SIAARTI (2019). La gestione perioperatoria del paziente con Sindrome delle Apnee Ostruttive del Sonno (OSA). Available at: http://www.siaarti.it/SiteA ssets/Ricerca/la-gestione-perioperatoria-del-paziente-con-Sindrome-delle-A pnee-Ostruttive-del-Sonno/Buone\%20Pratiche\%20Cliniche\%20SIAARTI\%2 0-\%20La\%20gestione\%20perioperatoria\%20del\%20paziente\%20con\%2 0Sindrome\%20delle\%20Apnee\%200struttive\%20del\%20Sonno.pdf. Accessed 27 Feb 2019

24. De Jong A, Molinari N, Terzi N et al (2013) Early identification of patients at risk for difficult intubation in the intensive care unit: development and validation of the MACOCHA score in a multicenter cohort study. Am J 
Respir Crit Care Med 187(8):832-839. https://doi.org/10.1164/rccm.201210-1 $8510 \mathrm{C}$

25. Umobong EU, Mayo PH (2018) Critical care airway management. Crit Care Clin 34(3):313-324. https://doi.org/10.1016/..ccc.2018.03.006

26. Levitan RM (2010) NO DESAT! Nasal oxygen during efforts securing a tube. Available at: http://www.epmonthly.com/features/current-features/no-desa t-\%. Accessed 15 Nov 2016.

27. Petrini F, Di Giacinto I, Cataldo R et al (2016) Perioperative and periprocedural airway management and respiratory safety for the obese patient: 2016 SIAARTI Consensus. Minerva Anestesiol 82(12):1314-1335

28. Ball L, Pelosi P (2019) How I ventilate an obese patient. Crit Care 23(1):176. https://doi.org/10.1186/s13054-019-2466-x

29. Ball L, Hemmes SNT, Serpa Neto A, Bluth T, Canet J, Hiesmayr M, Hollmann MW, Mills GH, Vidal Melo MF, Putensen C, Schmid W, Severgnini P, Wrigge H, Gama de Abreu M, Schultz MJ, Pelosi P, LAS VEGAS investigators, PROVE Network, Clinical Trial Network of the European Society of Anaesthesiology (2018) Intraoperative ventilation settings and their associations with postoperative pulmonary complications in obese patients. Br J Anaesth 121(4):899-908. https://doi.org/10.1016/j.jja.2018.04.021

30. Bazurro S, Ball L, Pelosi P (2018) Perioperative management of obese patient. Curr Opin Crit Care 24(6):560-567. https://doi.org/10.1097/MCC 0000000000000555

31. Brahmbhatt TS, Hernon M, Siegert CJ, Plauché L, Young LS, Burke P (2017) Trauma and BMI mortality. Curr Obes Rep 6(2):211-216. https://doi.org/10.1 007/s13679-017-0264-9

32. Gray S, Dieudonne B (2018) Optimizing care for trauma patients with obesity. Cureus 10:e3021. https://doi.org/10.7759/cureus.3021

33. Prottengeier J, Meyer M, Münster T (2014) Transfer of obese patients in european air ambulances. Eur J Emerg Med 21(5):377-379. https://doi.org/1 0.1097/MEJ.0000000000000098

34. Uppot RN (2018) Technical challenges of imaging \& image-guided interventions in obese patients. Br J Radiol 91:20170931. https:/doi.org/1 $0.1259 /$ bjr.20170931

35. Pépin JL, Timsit JF, Tamisier R, Borel JC, Lévy P, Jaber S (2016) Prevention and care of respiratory failure in obese patients. Lancet Respir Med 4(5): 407-418. https://doi.org/10.1016/\$2213-2600(16)00054-0

36. Nicolini A, Ferrando M, Solidoro P, Di Marco F, Facchini F, Braido F (2018) Non-invasive ventilation in acute respiratory failure of patients with obesity hypoventilation syndrome. Minerva Med 109(6 Suppl 1):1-5. https://doi. org/10.23736/S0026-4806.18.05921-9

37. Sequeira TCA, BaHammam AS, Esquinas AM (2017) Noninvasive ventilation in the critically ill patient with obesity hypoventilation syndrome: a review. J Intensive Care Med 32(7):421-428. https:/doi.org/10.1177/0885066616663179

38. Soghier I, Brożek JL, Afshar M, Kakazu MT, Wilson KC, Masa JF, Mokhlesi B (2019) Noninvasive ventilation versus cpap as initial treatment of obesity hypoventilation syndrome. Ann Am Thorac Soc 16(10):1295-1303. https:// doi.org/10.1513/AnnalsATS.201905-3800C

39. Chawla R, Dixit SB, Zirpe KG, Chaudhry D, Khilnani GC, Mehta Y, Khatib KI, Jagiasi BG, Chanchalani G, Mishra RC, Samavedam S, Govil D, Gupta S, Prayag S, Ramasubban S, Dobariya J, Marwah V, Sehgal I, Jog SA, Kulkarni AP (2020) ISCCM guidelines for the use of non-invasive ventilation in acute respiratory failure in adult ICUs. Indian J Crit Care Med 24(Suppl 1):S61-s81. https://doi.org/10.5005/jp-journals-10071-G23186

40. Davidson AC, Banham S, Elliott M et al (2016) BTS/ICS guideline for the ventilatory management of acute hypercapnic respiratory failure in adults. Thorax 71(Suppl 2):ii1-i35

41. Rowley DD, Arrington SR, Enfield KB, Lamb KD, Kadl A, Davis JP, Theodore DJ (2021) Transpulmonary pressure-guided lung-protective ventilation improves pulmonary mechanics and oxygenation among obese subjects on mechanical ventilation. Respir Care 66(7):1049-1058. https:/doi.org/10.4187/respcare.08686

42. Lemyze M, Guiot A, Granier M (2019) Esophageal pressure monitoring in the critically ill obese subject. Anesthesiology 130(3):441. https://doi.org/10.1 097/ALN.0000000000002499

43. Stroud T, Bagnall NM, Pucher PH (2018) Effect of obesity on patterns and mechanisms of injury: systematic review and meta analysis. Int J Surg 56: 148-154. https://doi.org/10.1016/j.jpsu.2018.05.004

44. Brunette DD (2004) Resuscitation of the morbidly obese patient. Am J Emerg Med 22(1):40-47. https://doi.org/10.1016/50735-6757(02)42250-4

45. Pucher PH, Tanno L, Hewage K, Bagnall NM (2017) Demand for specialised training for the obese trauma patient: national ATLS Expert Group survey results. Injury 48(5):1058-1062. https://doi.org/10.1016/j.injury.2017.02.027
46. Bochicchio GV, Joshi M, Bochicchio K, Nehman S, Tracy JK, Scalea TM (2006) Impact of obesity in the critically ill trauma patient: a prospective study. J Am Coll Surg 203(4):533-538. https://doi.org/10.1016/j.jamcollsurg.2006.07. 001

47. Ditillo M, Pandit V, Rhee P, Aziz H, Hadeed S, Bhattacharya B, Friese RS, Davis K, Joseph B (2014) Morbid obesity predisposes trauma patients to worse outcomes: a national trauma data bank analysis. J Trauma Acute Care Surg 76(1):176-179. https://doi.org/10.1097/TA.0b013e3182ab0d7c

48. Hatchimonji JS, Kaufman EJ, Vasquez CR, Shashaty MGS, Martin ND, Holena DN (2020) Obesity is associated with mortality and complications after trauma: a state-wide cohort study. J Surg Res 247:14-20. https://doi.org/10.1 016/j.jss.2019.10.047

49. Osborne Z, Rowitz B, Moore H, Oliphant U, Butler JA, Olson M, Aucar J (2014) Obesity in trauma: outcomes and disposition trends. Am J Surg 207(3):387-392; discussion 391-2. https://doi.org/10.1016/j.amjsurg.2013.10. 013

50. Parker BK, Manning S, Winters ME (2019) The crashing obese patient. West J Emerg Med 20(2):323-330. https://doi.org/10.5811/westjem.2018.12.41085

51. Bell T, Stokes S, Jenkins PC, Hatcher L, Fecher AM (2017) Prevalence of cardiovascular and respiratory complications following trauma in patients with obesity. Heart Lung 46(5):347-350. https://doi.org/10.1016/.hrtlng.2017. 05.010

52. Glance LG, Li Y, Osler TM, Mukamel DB, Dick AW (2014) Impact of obesity on mortality and complications in trauma patients. Ann Surg 259(3):576581. https://doi.org/10.1097/SLA.0000000000000330

53. Rock K, Hayward RD, Edhayan E (2019) Obesity and hospital outcomes following traumatic injury: associations in 9 years of patient data from a single metropolitan area. Clin Obes 9(2):e12293. https://doi.org/10.1111/ cob.12293

54. Dvorak JE, Lester ELW, Maluso PJ, Tatebe L, Schlanser V, Kaminsky M, Messer T, Dennis AJ, Starr F, Bokhari F (2020) The obesity paradox in the trauma patient: normal may not be better. World J Surg 44(6):1817-1823. https:// doi.org/10.1007/s00268-020-05398-1

55. Newell MA, Bard MR, Goettler CE, Toschlog EA, Schenarts PJ, Sagraves SG, Holbert D, Pories WJ, Rotondo MF (2007) Body mass index and outcomes in critically injured blunt trauma patients: weighing the impact. J Am Coll Surg 204(5):10561061; discussion 1062-4. https://doi.org/10.1016/j.jamcollsurg.2006.12.042

56. Belzberg H, Wo CC, Demetriades D, Shoemaker WC (2007) Effects of age and obesity on hemodynamics, tissue oxygenation, and outcome after trauma. J Trauma 62(5):1192-1200. https://doi.org/10.1097/01.ta.0000219701. 07295.b8

57. Nelson J, Billeter AT, Seifert B, Neuhaus V, Trentz O, Hofer C, Turina M (2012) Obese trauma patients are at increased risk of early hypovolemic shock: a retrospective cohort analysis of 1,084 severely injured patients. Crit Care 16(3):R77. https://doi.org/10.1186/cc11334

58. Shaikh S, Boneva D, Hai S, McKenney M, Elkbuli A (2020) Venous thromboembolism chemoprophylaxis regimens in trauma and surgery patients with obesity: a systematic review. J Trauma Acute Care Surg 88(4): 522-535. https://doi.org/10.1097/TA.0000000000002538

59. Parratte S, Pesenti S, Argenson JN (2014) Obesity in orthopedics and trauma surgery. Orthop Traumatol Surg Res 100(1):S91-S97. https://doi.org/10.1016/ j.otsr.2013.11.003

60. Nightingale CE, Margarson MP, Shearer E et al (2015) Peri-operative management of the obese surgical patient 2015: association of anaesthetists of Great Britain and Ireland Society for Obesity and Bariatric Anaesthesia. Anaesthesia 70:859-876

61. Pascarella G, Costa F, Cataldo R, Del Buono R, Carassiti M, Agrò FE (2020) Regional anesthesia in predicted difficult airway: US strategy for SOS (standards of safety). Reg Anesth Pain Med 46(3):285-286. https://doi.org/1 0.1136/rapm-2020-101548

62. Rosenthal J, Clark A, Campbell S, McMahon M, Arnoldo B, Wolf SE, Phelan H (2018) Effects of obesity on burn resuscitation. Burns 44(8):1947-1953. https://doi.org/10.1016/j.burns.2018.06.002

63. Tapking C, Houschyar KS, Rontoyanni VG, Hundeshagen G, Kowalewski KF, Hirche C, Popp D, Wolf SE, Herndon DN, Branski LK (2019) The influence of obesity on treatment and outcome of severely burned patients. J Burn Care Res 40(6):996-1008. https://doi.org/10.1093/jbcr/irz1 15

64. Secombe P, Sutherland R, Johnson R (2017) Body mass index and thoracic subcutaneous adipose tissue depth: possible implications for adequacy of chest compressions. BMC Res Notes 10(1):575. https://doi.org/10.1186/s131 04-017-2918-9 
65. Hans FP, Hoeren CJ, Kellmeyer P, Hohloch L, Busch HJ, Bayer J (2016) Possibly preventable cardiac arrest in a morbidly obese patient - a comment on the 2015 ERC Guidelines. Scand J Trauma Resusc Emerg Med 24(1):116. https://doi.org/10.1186/s13049-016-0306-4

66. Lee J, Oh J, Lim TH, Kang H, Park JH, Song SY, Shin GH, Song Y (2018) Comparison of optimal point on the sternum for chest compression between obese and normal weight individuals with respect to body mass index, using computer tomography: a retrospective study. Resuscitation 128 : 1-5. https://doi.org/10.1016/j.resuscitation.2018.04.023

67. Nishisaki A, Maltese MR, Niles DE, Sutton RM, Urbano J, Berg RA, Nadkarni VM (2012) Backboards are important when chest compressions are provided on a soft mattress. Resuscitation 83(8):1013-1020. https://doi.org/1 0.1016/j.resuscitation.2012.01.016

68. Secombe PJ, Sutherland R, Johnson R (2018) Morbid obesity impairs adequacy of thoracic compressions in a simulation-based model. Anaesth Intensive Care 46(2):171-177. https://doi.org/10.1177/0310057X1804600205

69. Tellson A, Qin H, Erwin K, Houston S (2017) Efficacy of acute care health care providers in cardiopulmonary resuscitation compressions in normal and obese adult simulation manikins. Proc (Baylor Univ Med Cent) 30(4): 415-418. https://doi.org/10.1080/08998280.2017.11930210

70. Wang $\mathrm{CH}$, Huang $\mathrm{CH}$, Chang WT, Tsai MS, Yu PH, Wu YW, Hung KY, Chen WJ (2016) The influences of adrenaline dosing frequency and dosage on outcomes of adult in-hospital cardiac arrest: a retrospective cohort study. Resuscitation 103:125-130. https://doi.org/10.1016/j.resuscitation.2015.12.008

71. Gough CJR, Nolan JP (2018) The role of adrenaline in cardiopulmonary resuscitation. Crit Care 22(1):139. https://doi.org/10.1186/s13054-018-2058-1

72. Cataldo R, Di Giacinto I, Sorbello M, Petrini F (2020) Emergency anesthesia and resuscitation in the patient with obesity. In: Foschi D (ed) Emergency Surgery in Obese Patients. Springer, Berlin

73. Meng L, Mui E, Holubar MK, Deresinski SC (2017) Comprehensive guidance for antibiotic dosing in obese adults. Pharmacotherapy 37(11):1415-1431. https://doi.org/10.1002/phar.2023

74. Smit C, De Hoogd S, Brüggemann RJM, Knibbe CAJ (2018) Obesity and drug pharmacology: a review of the influence of obesity on pharmacokinetic and pharmacodynamic parameters. Expert Opin Drug Metab Toxicol 14(3):275-285. https://doi.org/10.1080/17425255.2018.14402 87

75. de Caen AR, Berg MD, Chameides L, Gooden CK, Hickey RW, Scott HF, Sutton RM, Tijssen JA, Topjian A, van der Jagt ÉW, Schexnayder SM, Samson RA (2015) Part 12: Pediatric advanced life support: 2015 American Heart Association Guidelines Update for Cardiopulmonary Resuscitation and Emergency Cardiovascular Care. Circulation 132(18 suppl 2):S526-S542. https://doi.org/10.1161/CIR.0000000000000266

76. Callaway CW, Donnino MW, Fink EL, Geocadin RG, Golan E, Kern KB, Leary M, Meurer WJ, Peberdy MA, Thompson TM, Zimmerman JL (2015) Part 8: Post-cardiac arrest care: 2015 Aamerican Heart Association Guidelines Update for Cardiopulmonary Resuscitation and Emergency Cardiovascular Care. Circulation 132(18 Suppl 2):S465-S482. https://doi.org/10.1161/CIR. 0000000000000262

77. Donnino MW, Andersen LW, Berg KM, Reynolds JC, Nolan JP, Morley PT, Lang E, Cocchi MN, Xanthos T, Callaway CW, Soar J, ILCOR ALS Task Force (2015) Temperature management after cardiac arrest: an advisory statement by the advanced life support task force of the International Liaison Committee on Resuscitation and the American Heart Association Emergency Cardiovascular Care Committee and the Council on Cardiopulmonary, Critical Care, Perioperative and Resuscitation. Circulation 132(25):2448-2456. https://doi.org/10.1161/CIR. 0000000000000313

78. Dankiewicz J, Cronberg T, Lilja G, Jakobsen JC, Levin H, Ullén S, Rylander C, Wise MP, Oddo M, Cariou A, Bělohlávek J, Hovdenes J, Saxena M, Kirkegaard H, Young PJ, Pelosi P, Storm C, Taccone FS, Joannidis M, Callaway C, Eastwood GM, Morgan MPG, Nordberg P, Erlinge D, Nichol AD, Chew MS, Hollenberg J, Thomas M, Bewley J, Sweet K, Grejs AM, Christensen S, Haenggi M, Levis A, Lundin A, Düring J, Schmidbauer S, Keeble TR, Karamasis GV, Schrag C, Faessler E, Smid O, Otáhal M, Maggiorini M, Wendel Garcia PD, Jaubert P, Cole JM, Solar M, Borgquist O, Leithner C, AbedMaillard S, Navarra L, Annborn M, Undén J, Brunetti I, Awad A, McGuigan P, Bjørkholt Olsen R, Cassina T, Vignon P, Langeland $H$, Lange T, Friberg H, Nielsen N (2021) Hypothermia versus normothermia after out-of-hospital cardiac arrest. N Engl J Med 384(24):2283-2294. https://doi.org/10.1056/ NEJMoa2100591
79. Leary M, Cinousis MJ, Mikkelsen ME, Gaieski DF, Abella BS, Fuchs BD (2014) The association of body mass index with time to target temperature and outcomes following post-arrest targeted temperature management. Resuscitation 85(2):244-247. https://doi.org/10.1016/j. resuscitation.2013.10.027

80. Jung YH, Lee BK, Lee DH, Lee SM, Cho YS, Jeung KW (2017) The association of body mass index with outcomes and targeted temperature management practice in cardiac arrest survivors. Am J Emerg Med 35(2):268-273. https:// doi.org/10.1016/j.ajem.2016.10.070

81. Breathett K, Mehta N, Yildiz V, Abel E, Husa R (2016) The impact of body mass index on patient survival after therapeutic hypothermia after resuscitation. Am J Emerg Med 34(4):722-725. https://doi.org/10.1016/j.a jem.2015.12.077

82. Geri G, Savary G, Legriel S, Dumas F, Merceron S, Varenne O, Livarek B, Richard O, Mira JP, Bedos JP, Empana JP, Cariou A, Grimaldi D (2016) Influence of body mass index on the prognosis of patients successfully resuscitated from out-of-hospital cardiac arrest treated by therapeutic hypothermia. Resuscitation 109:49-55. https://doi.org/10.1016/j.resuscita tion.2016.09.011

83. Garg S, Kim L, Whitaker M, O'Halloran A, Cummings C, Holstein R, Prill M, Chai SJ, Kirley PD, Alden NB, Kawasaki B, Yousey-Hindes K, Niccolai L, Anderson EJ, Openo KP, Weigel A, Monroe ML, Ryan P, Henderson J, Kim S, Como-Sabetti K, Lynfield R, Sosin D, Torres S, Muse A, Bennett NM, Billing L, Sutton M, West N, Schaffner W, Talbot HK, Aquino C, George A, Budd A, Brammer L, Langley G, Hall AJ, Fry A (2020) Hospitalization rates and characteristics of patients hospitalized with laboratory-confirmed coronavirus disease 2019 - COVID-Net, 14 states, March 1-30, 2020. MMWR Morb Mortal Wkly Rep 69(15):458-464. https://doi.org/10.15585/mmwr. $\mathrm{mm} 6915 \mathrm{e} 3$

84. Maddaloni E, D'Onofrio L, Alessandri F et al (2020) Clinical features of patients with type 2 diabetes with and without covid-19: a case control study (CoViDiab I). Diabetes Res Clin Pract 169:108454. https://doi.org/10.101 6/j.diabres.2020.108454

85. Maddaloni E, D'Onofrio L, Alessandri F, Mignogna C, Leto G, Pascarella G, Mezzaroma I, Lichtner M, Pozzilli P, Agrò FE, Rocco M, Pugliese F, Lenzi A, Holman RR, Mastroianni CM, Buzzetti R, the CoViDiab Study Group, Ajassa C, Alban R, Alessandri F, Alessi F, Aronica R, Belvisi V, Buzzetti R, Candy M, Caputi A, Carrara A, Casali E, Cavallari EN, Ceccarelli G, Celani L, Ciardi MR, Coraggio L, Curtolo A, D'Agostino C, D'Ettorre G, D'Onofrio L, de Giorgi F, de Girolamo G, Filippi V, Gnessi L, Luordi C, Maddaloni E, Mastroianni CM, Mezzaroma I, Mignogna C, Moretti C, Pugliese F, Recchia G, Ridolfi M, Romani FE, Russo G, Ruberto F, Savelloni G, Siccardi G, Siena A, Sterpetti S, Valeri S, Vera M, Volpicelli L, Watanabe M, Aiuti M, Campagna G, del Borgo C, Fondaco L, Kertusha B, Leonetti F, Leto G, Lichtner M, Marocco R, Masala R, Zuccalà P, Agrò FE, Nonnis G, Pascarella G, Pozzilli P, Rigoli A, Strumia A, Alampi D, Rocco M (2020) Cardiometabolic multimorbidity is associated with a worse COVID-19 prognosis than individual cardiometabolic risk factors: a multicentre retrospective study (CoViDiab II). Cardiovasc Diabetol 19(1):164. https://doi.org/10.1186/s12933-020-01140-2

86. Pascarella G, Strumia A, Piliego C, Bruno F, del Buono R, Costa F, Scarlata S, Agrò FE (2020) COVID-19 diagnosis and management: a comprehensive review. J Intern Med 288(2):192-206. https://doi.org/1 0.1111/joim. 13091

87. Cummings MJ, Baldwin MR, Abrams D, Jacobson SD, Meyer BJ, Balough EM, Aaron JG, Claassen J, Rabbani LRE, Hastie J, Hochman BR, Salazar-Schicchi J, Yip NH, Brodie D, O'Donnell MR (2020) Epidemiology, clinical course, and outcomes of critically ill adults with covid-19 in new york city: a prospective cohort study. Lancet 395(10239):1763-1770. https://doi.org/10.1016/S01406736(20)31189-2

88. Forest SJ, Michler RE, Skendelas JP, DeRose JJ, Friedmann P, Parides MK, Forest SK, Chauhan D, Goldstein DJ (2021) De novo renal failure and clinical outcomes of patients with critical coronavirus disease 2019. Crit Care Med 49(2):e161-e169. https://doi.org/10.1097/CCM.0000000000004785

89. Richardson S, Hirsch JS, Narasimhan M, Crawford JM, McGinn T, Davidson KW, and the Northwell COVID-19 Research Consortium, Barnaby DP, Becker LB, Chelico JD, Cohen SL, Cookingham J, Coppa K, Diefenbach MA, Dominello AJ, Duer-Hefele J, Falzon L, Gitlin J, Hajizadeh N, Harvin TG, Hirschwerk DA, Kim EJ, Kozel ZM, Marrast LM, Mogavero JN, Osorio GA, Qiu M, Zanos TP (2020) Presenting characteristics, comorbidities, and outcomes among 5700 patients hospitalized with COVID-19 in the New York City area. Jama 323(20):2052-2059. https://doi.org/10.1001/jama.2020.6775 
90. Istituto Superiore di Sanità (2020) Characteristics of SARS-CoV-2 patients dying in Italy Report based on available data on July 22, 2020. Available at: https://www.epicentro.iss.it/en/coronavirus/bollettino/Report-COVID-201 9_22_july_2020.pdf. Accessed 22 Jul 2020.

91. Sorbello M, El-Boghdadly K, Di Giacinto I et al (2020) The Italian coronavirus disease 2019 outbreak: recommendations from clinical practice. Anaesthesia 75(6):724-732. https://doi.org/10.1111/anae.15049

92. Belančić A, Kresović A, Rački V (2020) Potential pathophysiological mechanisms leading to increased COVID-19 susceptibility and severity in obesity. Obes Med 19:100259. https://doi.org/10.1016/j.obmed.2020.100259

93. Hussain A, Mahawar K, Xia Z, Yang W, El-Hasani S (2020) Obesity and mortality of COVID-19. Meta-analysis. Obes Res Clin Pract 14(4):295-300. https://doi.org/10.1016/j.orcp.2020.07.002

94. Suen CM, Hui DSC, Memtsoudis SG, Chung F (2020) Obstructive sleep apnea, obesity, and noninvasive ventilation: considerations during the COVID-19 pandemic. Anesth Analg 131(2):318-322. https://doi.org/1 0.1213/ANE.0000000000004928

95. Clément K, Coupaye M, Laville M, Oppert JM, Ziegler O (2020) COVID-19: a lever for the recognition of obesity as a disease? The French experience. Obesity (Silver Spring) 28(9):1584-1585. https://doi.org/10.1002/oby.22924

96. Kwok S, Adam S, Ho JH, Iqbal Z, Turkington P, Razvi S, le Roux CW, Soran H, Syed AA (2020) Obesity: a critical risk factor in the COVID-19 pandemic. Clin Obes 10(6):e12403. https://doi.org/10.1111/cob.12403

97. Umbrello M, Fumagalli J, Pesenti A, Chiumello D (2019) Pathophysiology and management of acute respiratory distress syndrome in obese patients. Semin Respir Crit Care Med 40(1):40-56. https://doi.org/10.1055/s-0039-1 685179

98. European Resuscitation Council (2019) ERC Quality standards for cardiopulmonary resuscitation practice and training Available at: https:// www.erc.edu/sites/5714e77d5e615861f00f7d18. Accessed 5 Dec 2019.

99. Sorbello M, Di Giacinto I, Falcetta S, Greif R (2020) Ventilation and airway management during cardiopulmonary resuscitation in COVID-19 era. Resuscitation 153:35-36. https://doi.org/10.1016/j.resuscitation.2020.05.043

100. Ryan DH, Ravussin E, Heymsfield S (2020) COVID 19 and the patient with obesity - the editors speak out. Obesity 28(5):847. https://doi.org/10.1002/ oby. 22808

101. Muscogiuri G, Pugliese G, Barrea L, Savastano S, Colao A (2020) Commentary: Obesity: the "Achilles heel" for COVID-19? Metabolism 108: 154251. https://doi.org/10.1016/.metabol.2020.154251

102. Watanabe M, Risi R, Tuccinardi D, Baquero CJ, Manfrini S, Gnessi L (2020) Obesity and SARS-CoV-2: a population to safeguard. Diabetes Metab Res Rev:e3325

\section{Publisher's Note}

Springer Nature remains neutral with regard to jurisdictional claims in published maps and institutional affiliations.

Ready to submit your research? Choose BMC and benefit from:

- fast, convenient online submission

- thorough peer review by experienced researchers in your field

- rapid publication on acceptance

- support for research data, including large and complex data types

- gold Open Access which fosters wider collaboration and increased citations

- maximum visibility for your research: over $100 \mathrm{M}$ website views per year

At BMC, research is always in progress.

Learn more biomedcentral.com/submissions 